\title{
PROPOSED CHANGES TO THE CROTIS TOPOGRAPHIC MODEL FOR THE BASIC PACKAGE AND THE OBJECT ENTITY OF HYDROGRAPHY
}

\author{
Ivan LANDEK, Saša CVITKOVIĆ, Milan REZO
}

\begin{abstract}
In 1992, the State Geodetic Administration started with the development of cartography in the Republic of Croatia. After making a certain number of studies, STOKIS (the Official Topographic-Cartographic Information System) was defined. Topographic and cartographic data models were then defined by STOKIS. According to the STOKIS guidelines, the Croatian topographic information system (CROTIS) was developed as a data model and on the basis of CROTIS, the Basic Topographic Database (TTB) was established. One thematic entity contained in CROTIS 2.0, and whose data is often used, is the object entity of Hydrography. This article will provide an insight into the need to expand/correct the TTB data model in relation to the underlying basic package and the object entity of Hydrography, all in line with international standards and the INSPIRE directive.
\end{abstract}

Keywords: CROTIS; hydrography; topography; TTB

\section{INTRODUCTION}

Previously, in the former state, the Republic of Croatia was one of the six federal republics until gaining independence (1991) and international recognition (1992). In the former state, the production of topographic maps in the scale of 1:25 000 (TM25>TK25) and smaller was exclusively under the jurisdiction of the federal military authority, respectively in the institution responsible for this activity, which was the Military Geographic Institute (MGI>VGI) in Belgrade. The Republic Geodetic Administration in Croatia could only order a certain number of printed copies of topographic maps (only civilian publications). After the proclamation of independence, the Republic of Croatia was without the possibility of printing and updating the topographic maps because the reproductive originals were still only in MGI>VGI [11]. Later, during the Homeland War, copies of some remaining maps were used [12].

Major changes in space caused by war events, the demographic changes, as well as the general progress of the society, followed by strong technological development and excessive spending of natural resources, have significantly influenced the awareness of the priceless value of the space we live in. Therefore, thoughtful use, purposeful planning and systematic environmental protection of the space we live in have become very important tasks of the modern society. In this process, information about the space we live in is extremely important [13]. In the past, spatial data were mainly in the form of cartographic representation, and more recently, digital data is being used in the form of spatial databases for various designing, spatial planning, making of various studies etc.

In 1992, the Republic of Croatia began with the independent development of topographic cartography. The State Geodetic Administration (SGA $>$ DGU), in cooperation with other relevant experts from the academia and private companies that had a long-standing experience in the production of large scale maps, has launched several studies and the designing of a future topographic and cartographic system. The result of these activities is the creation of the official topographic and cartographic information system in 1993 which was named STOKIS. The current STOKIS data model is shown in Fig. 1 [2].

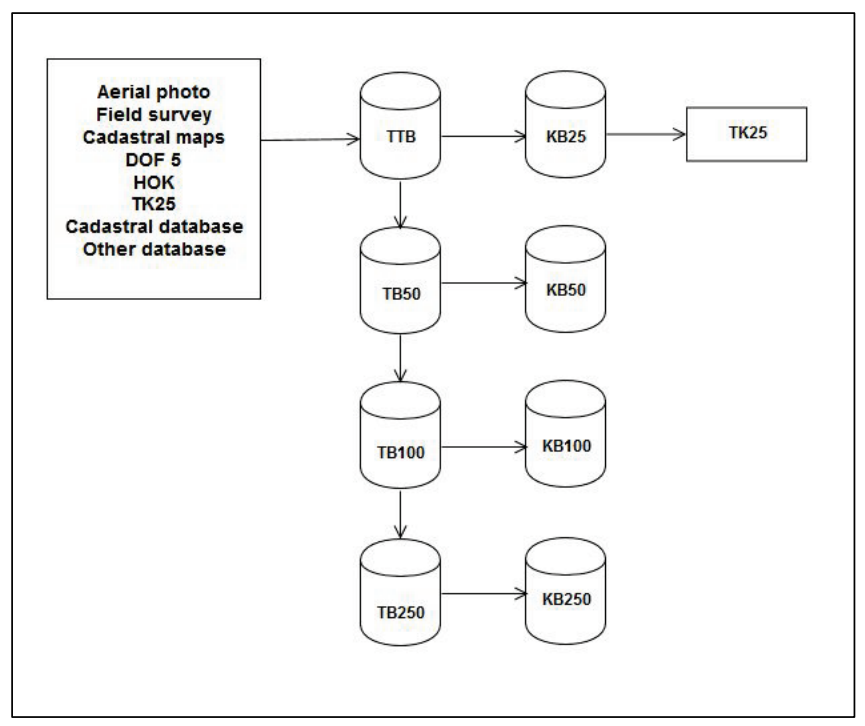

Figure 1 STOKIS Data Model

According to Article 23 of the Ordinance on Topographic Survey and State Maps Designs [1], the basic principles for the establishment of topographic and cartographic databases conforming to STOKIS are laid down, and Article 25 specifies the creation of topographic databases (TTB). Article 26 of the Ordinance clarifies the model of the creation of cartographic databases (KB).

After the establishment of STOKIS, an analysis was carried out to make the model of the data, which would be the most suitable for the current situation in the Republic of Croatia. 
For a research of the state of geospatial data in the Republic of Croatia [5], a large number of experts were hired to collect data on the need and usage of geospatial information in different fields. When the research and analysis of the collected data were done, the Croatian Topographic Information System of the Republic of Croatia (CROTIS) was proposed and adopted [6].

Based on the Croatian Topographic Information System (CROTIS), in the period from 2003 to 2010, the Basic Topographic Database (TTB) was established. TTB is the basis for the first edition of the Topographic Map at a scale of 1:25000 (TK25), as well as for all topographic maps that will be developed in the future. During the creation of the basic topographic database, a deficit of objects in the data model was noticed. This paper aims to supplement the existing data model to better classify the collected data into certain thematic entities or classes. The intention is to reduce the possibility that there is an object on the ground and that when data is collected, we do not know where to place it or we do not have where to place it (we do not have an object entity or class and we cannot assign a value to the attribute). The proposal for improvement is based on the experience and comments/suggestions from the data collection process and the creation of a Basic Topographic Database by the contractors and employees of SGA who have been working on data quality control.

\section{DEVELOPMENT OF THE CROATIAN TOPOGRAPHIC INFORMATION SYSTEM (CROTIS)}

The official topographic-cartographic information system [4] is the fundamental document in which the strategy of multiannual cartographic development in the Republic of Croatia has been written. After the establishment of STOKIS, an analysis has been carried out to make the model of the data which would be the most suitable for the current situation in the Republic of Croatia. CROTIS is the basic document for topographic data that prescribes the classification of topographic data in their collection, processing, accuracy, topological relations and exchange of topographic data. Data which is obtained by photogrammetric restitution and topological processing is stored in the Basic Topographic Database (TTB). TTB was established in the year 2003, and at the end of 2010, the first initial upload of TTB data for the entire territory of the Republic of Croatia was completed [3].

The first version of the CROTIS data model was made based on the ATKIS (Amliches TopographischKartographishes Informationssystem - German Official Topographic Cartographic Information System) data model. ATKIS is a project of the Working Committee of the Surveying Authorities of the Laender of the Federal Republic of Germany, consisting of one Digital Topographic Model (DLM) and Multiple Digital Cartographic Models (DKM), and is annex to classical analogue (printed) maps. The Republic of Croatia did not have any experience about the production of topographic maps at the scale larger than the 1:5000 scale (Croatian Basic Map - HOK). Parallel with the independence of the Republic of Croatia in the year 1991, analyses for the most suitable data model for the Republic of
Croatia began. After the analysis and the production of numerous studies in cooperation with the professors at the Faculty of Geodesy in Zagreb, the staff of the State Geodetic Administration and the experts in the field of cartography, it was concluded that ATKIS was the most appropriate data model and according to it, a data model for the Republic of Croatia should be established. In the period between 1990 and 1996, several studies were produced which provided the basic determinants for the topographic data model named CROTIS 1.0. The CROTIS 1.0 data model (Tab. 1) is a defined and standardized data model for the collecting, processing, accuracy, topological relations and exchange of topographic data [3].

Table 1 CROTIS 1.0, CROTIS 1.2, CROTIS 2.0 data model object entities

\begin{tabular}{|l|l|l|}
\hline \multicolumn{1}{|c|}{ CROTIS 1.0 } & \multicolumn{1}{|c|}{ CROTIS 1.2 } & \multicolumn{1}{c|}{ CROTIS 2.0 } \\
\hline 1000 Permanent geodetic & 1000 Permanent geodetic & \\
\hline $\begin{array}{l}2000 \text { Buildings, commercial and } \\
\text { public objects }\end{array}$ & $\begin{array}{l}2000 \text { Buildings, commercial and } \\
\text { public objects }\end{array}$ & Buildings \\
\hline 3000 Utility lines & 3000 Utility lines & Utility lines \\
\hline 4000 Transport & 4000 Transport & Transport \\
\hline 5000 Vegetation and land types & 5000 Vegetation and land types & Land cover and land use \\
\hline 6000 Waters & 6000 Waters & Hydrography \\
\hline 7000 Relief & 7000 Relief & Relief \\
\hline $\begin{array}{l}\text { 8000 Administrative and } \\
\text { territorial division, boundaries }\end{array}$ & $\begin{array}{l}8000 \text { Administrative and- } \\
\text { territerialdivision, boundaries }\end{array}$ & \\
\hline 9000 Geographical names & 1000 Geographical names & Geographical names \\
\hline
\end{tabular}

The data model consisted of 9 object entities, 31 object groups, and 101 object types. Object entities that made up the first CROTIS 1.0 document were: permanent geodetic points, buildings, commercial and public objects, utility lines, transport, vegetation and land types, waters, relief, administrative and territorial division, boundaries and geographical names (toponyms) (Tab. 1).

After the CROTIS 1.0 data model, the version CROTIS 1.1 was created [15]. By conducting additional analyses and due to the technological progress, it was concluded that the EXPRESS exchange format was to be accepted, which was a universal exchange format at that time. CROTIS 1.1. was created in 2002. In the CROTIS 1.1 data model, 9 object entities were kept, as well as in the CROTIS 1.0 data model.

Subsequently, the CROTIS 1.2 data model was created. (Tab. 1) In it, the object entities of permanent geodetic points, as well as the administrative and territorial division and boundaries, were extracted and maintained in separated databases. The CROTIS 1.2. data model was adopted in 2006 [3].

Having in mind the technological advances in the field of spatial data and EU directives, new occurrences in the development of spatial data happened. At that time, the Republic of Croatia had a pre-accession agreement with the European Union and all the information regarding spatial data was closely followed. The EU issued the INSPIRE 2007/2/EC Directive of the European Parliament and the Council of the European Union on 14 March 2007. The CROTIS 2.0 data model [7] was largely aligned with the INSPIRE directive and adopted in 2014 [8]. The basic idea of the Directive is to share (exchange) spatial data among all interested parties, and considering the fact that the scope of the INSPIRE themes is very extensive, CROTIS 2.0 met the 
basic components of the concepts of interoperability and harmonization - also known as the components of interoperability [9].

In CROTIS 2.0 (Tab. 1), the data model was modified so that Relief (3D) was excluded and the object entity of Vegetation and Land Type was renamed into Land Cover and Land Use. Compared to the previous versions of the data model, this version was minimally expanded with new content. The newly created object classes, attributes, and values are the result of a new approach to objects grouping, a new catalog of objects and aligning names with definitions, all in order to minimize the number of unidentified objects. Furthermore all object classes that are an integral part of the Digital Relief Model (DRM) are also omitted from the Relief object entity. Major changes were also made in the former entity of Vegetation and Land Types, and the Land Use Class was introduced as a special layer within an entity which conceptually differs from other classes within the Coverage and Land Use. The biggest change occurred in the way of displaying area objects, since the data collection was adapted to primitive graphic elements (point, line), so the area objects consisted of boundaries (lines) that contained the attributes of the area object. In the new model, each object can have one of the three predefined geometries (point, line, polygon) and contains all the attributes provided by the model [14]. In addition to the definition of object entities, attributes and classes, in the new model, attribute values definitions are also provided. In the CROTIS 2.0 model, the abstract object of upper-class "CROTIS objects" has been introduced, which is the carrier of the basic attributes of all classes in the model, for example the unique identifier, accuracy of collection, origin, life cycle of the object and so on [3].

CROTIS 2.0 is a topographic model similar to the topographic models of the Kingdom of Denmark and the Netherlands [10], in which topographic databases are in the scale of 1:10 000 [3].

\section{CROATIAN TOPOGRAPHIC INFORMATION SYSTEM - CROTIS 2.0}

The Croatian topographic information system (CROTIS 2.0) consists of seven object entities, namely: Geographical Names, Buildings, Transport, Land Cover and Land Use, Utility, Relief and Hydrography (Fig. 2).

The object entity of Geographical Names consists of the class: GeographicalName, and the list of allowed attribute values of the class: GeographicalNameCategoryType and GeographicalNameType.

The object entity of Buildings consists of the following classes: Abstract Buildings, Buildings, BuiltBarriers, SmallStructures, PurposeType, BigStructures, VerticalLevelType, BuiltBarrierType, OtherStructuresType, BuildingType and Building.

The components of the object entity of Transport consist of the following classes: Transport Elements, Curve Transport Elements, Road Axis, Surface Transport Elements, Traffic Area, Rail and the list of allowed attributes of the class: Road Category Type, Transport Category Type, Rail Type, Type of Transport Element Value, Type of Pavement
Value, Type of Road Axis, Type of Traffic Area Value, Rail Category Type.

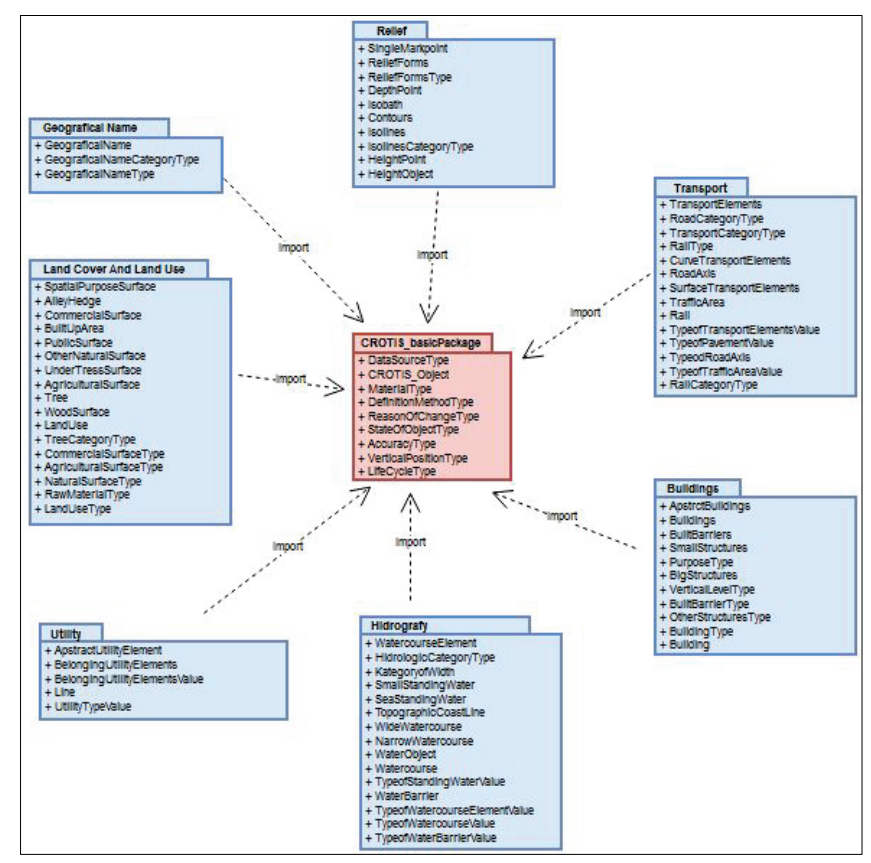

Figure 2 CROTIS 2.0 object entities

The object entity of Land Cover and Land Use consists of the following classes: Spatial Purpose Surface, Alley Hedge, Commercial Surface, Built-up Area, Public Surface, Other Natural Surface, Under Tree Surface, Agriculture Surface, Tree, Wood Surface, Land Use, and the list of allowed attributes of the class: Tree Category Type, Commercial Surface Type, Agricultural Surface Type, Natural Surface Type, Raw Material Type, Land Use Type.

According to the topographic data model of CROTIS 2.0, the object entity of Utility consists of the class: Abstract Utility Element, Belonging Utility Element, Line, and the list of allowed attributes of the class: Belonging Utility Element Value, Utility Type Value.

The object entity of Relief consists of the following classes: Single Mark Point, Relief Forms, Depth Point, Isobath, Contours, Isolines, Height Point, Height Object, and the list of allowed attributes of the class: Relief Forms Type, Isolines Category Type.

Finally, the object entity of Hydrography consists of the following classes: Watercourse Element, Sea Standing Water, Small Standing Water, Topographic Coast Line, Wide Watercourse, Narrow Watercourse, Water Object, Watercourse, Water Barrier, and the list of allowed attributes of the class: Hydrologic Category Type, Type of Standing Water Value, Type of Watercourse Element Value, Type of Watercourse Value, Type of Water Barrier Value.

All listed object entities contain a basic package consisting of the following upper-class: FeatureType CROTIS_Object and dataType Life Cycle Type and the list of allowed attributes of the upper-class: enumeration Accuracy Type, enumeration Definition Method Type, code list Vertical Position Type, code List Material Type, code 
List Dana >source Type, code list Reason of change type and code list State of Object Type. (Fig. 3).

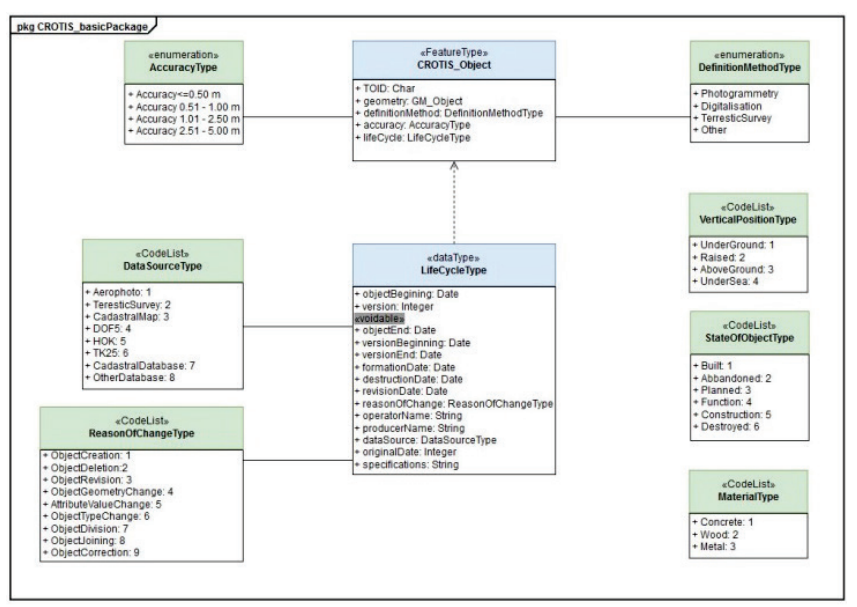

Figure 3 CROTIS 2.0_basic package

The article depicts images with diagrams marked with different colors which have the following meaning:

- $\quad$ red color - base Package (entity)

- blue color - upper-class or class

- green color - list of allowed values of the upper-class or class attribute.

\section{PROPOSED IMPROVEMENT OF THE CROATIAN TOPOGRAPHIC INFORMATION SYSTEM - CROTIS 2.1}

The CROTIS 2.0 topographic data model is largely in line with the INSPIRE 2007/2/EC directive. However, a careful analysis has shown some inconsequence that we will present and propose the correction of, thereby improving CROTIS 2.0. The proposal of a new upgraded topographic information system will be labeled as CROTIS 2.1.

\subsection{CROTIS 2.1_basicPackage}

Changes to the CROTIS 2.0 topographic model in relation to CROTIS 2.1 topographic model will be explained in an italic text.

The CROTIS 2.1_basicPackage does not differ from the CROTIS 2.0_basicPackage in the number and title of classes and upper-class, and it contains the following upper-classes: FeatureType CROTIS_Object and DataType LifeCycleType, and a list of allowed values of the upper-class attributes: AccuracyType, DefinitionMethodType, VerticalPositionType, StateOfObjectType, MaterialType, ReasonsOfChangeType and DataSourceType (Fig. 4).

In the CROTIS 2.1_basicPackage topographic model (Fig. 4), the following improvements are proposed:

In the code list (CodeList), the StatusOfObjectType excludes attribute values and codes: Abandoned: 2 and InFunction: 4. This part is unnecessary since the primary purpose of collecting data in TTB is not to know whether or not a building is in use or not or whether it is in function. This type of information is collected and maintained by other institutions. If the object is in function, the assumption is that the object is built, and that the attribute already exists.

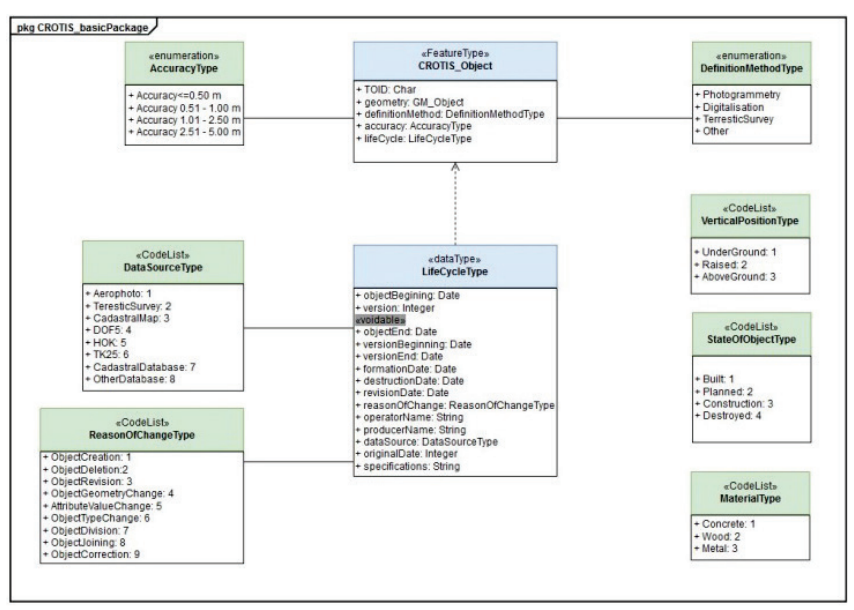

Figure 4 CROTIS 2.1_basic package

Therefore, in the CROTIS 2.1_basicPackage topographic data model (Fig. 4), the code list (CodeList) of the StatusOfObjectType should consist of the following attribute values and codes:

\section{Built: 1, Planned: 2, InDevelopment: 3, Destroyed: 4.}

In the CROTIS 2.1 basicPackage topographic data model (Fig. 4), in the code list (CodeList) of the Vertical PositionType, the proposition is to exclude the values and codes of the value of the attribute: UnderSea: 4, as these data are under the responsibility of the Croatian Hydrographic Institute (CHI), and additionally, the majority of the data collected and maintained in TTB is from photogrammetric images where the data below the sea cannot be detected and collected. Data which is available to the $\mathrm{CHI}$ are very specific and required for a smaller and more specific group of users.

Therefore, in the CROTIS 2.1_basicPackage topographic data model (Fig. 4), the code list (CodeList) of VerticalPositionType consisted of the following attribute values and codes:

\section{UnderGround: 1, Raised: 2, AboveGround: 3}

The upper-class feature type of CROTIS_Object and the data type of LifeCycleType, as well as the list of allowed values of the upper-class attribute values, AcurracyType, VerticalPositionType, StateOfObjectType, MaterialType, ReasonOfChangeType and DataSourceType (Fig. 4), will all remain the same, except for the above-mentioned changes, as it is the case in the CROTIS 2.0 _basicPackage topographic data model (Fig. 3).

\subsection{CROTIS 2.1_ object entity Hydrography}

The object entity of Hydrography is intended for storing and displaying all waters: streams and stands, underwater objects, natural and built objects on watercourses that in any way affect water flow or retain water. Fig. 5 depicts in detail 
the object entity of Hydrography according to the CROTIS 2.0 data model.

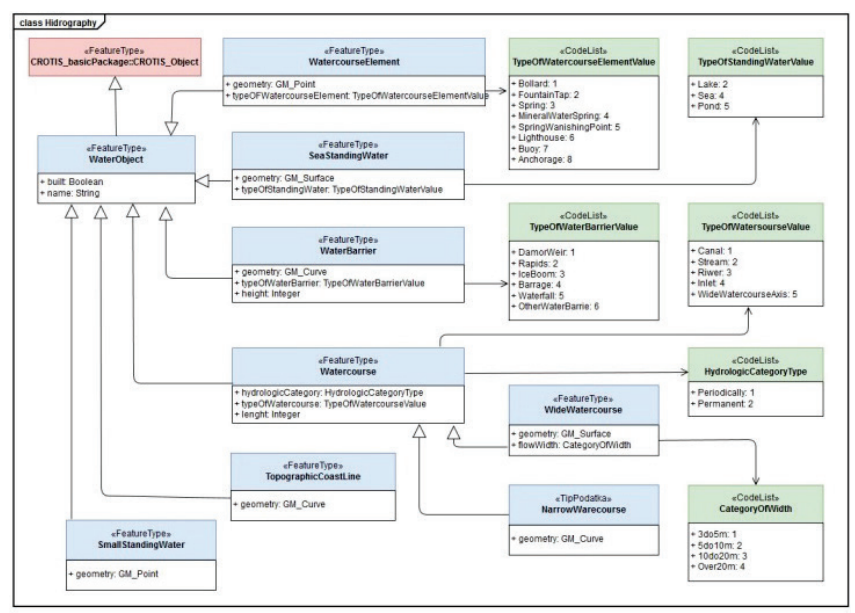

Figure 5 CROTIS 2.0_Hydrography

In the topographic data model of CROTIS 2.1, the object entity of the Hydrography (Fig. 6), the proposal is to add, in the class feature type of Watercourse, the value of attribute navigability: Boolean.

Thus, in the topographic model of CROTIS 2.1, the object entity of Hydrography (Fig. 6) in the class of FeatureType Watercourse would consist of the following titles and attribute types:

hydrologicCategory: HydrologicCategoryType, typeOfWatercourse: typeOfWatercourseValue length: Integer, navigability: Boolean.

In the topographic data model of CROTIS 2.1, the object entity of Hydrography (Fig. 6), the proposal is to add, in the code list the HydrologicCategoryType, the value and attribute value codes: Dry: 3 .

Thus, in the topographic model of CROTIS 2.1, the object entity of Hydrography (Fig. 6), the CodeList HydrologicCategoryType would contain the following values and attribute values codes:

\section{Periodically: 1, Permanent: 2, Dry: 3}

In the topography model of CROTIS 2.1, the object entity Hydrography (Fig. 6), the proposal is to add, in the CodeList TypeOfWatercourseElementValue, the value and attribute value codes: Puddle: 9 .

Thus, in the topographic model of CROTIS 2.1, the object entity of Hydrography (Fig. 6), the CodeList TypeOfWatercourseElementValue would contain the following values and attribute values codes:

Bollard: 1, FountainTap: 2, Spring: 3,

MineralWaterSpring: 4, SpringWanishingPoint: 5,

Lighthouse: 6, Buoy: 7, Anchorage: 8, Puddle: 9

In the topography model of CROTIS 2.1, the object entity of Hydrography (Figure 6), the proposal is to add, in the CodeList TypeOfStandingWaterValue, the values and attribute value codes: Plash: 6 .

Thus, in the topographic model of CROTIS 2.1, the object entity of Hydrography (Fig. 6), the CodeList TypeOfStandingWaterValue would contain the following values and attribute values codes:

\section{Lake: 2, Sea: 4, Pond: 5, Plash: 6}

In the topographic data model of CROTIS 2.1, the object entity of Hydrography (Fig. 6), the proposal is to delete the value and attribute value codes in the CodeList CategoryOfWidthType: 5 do10m: 2 .

The cartographic key for TK25 and Product Specifications for TTB define that narrow watercourses up to $3 \mathrm{~m}$ in width are displayed as line objects; watercourses from 3 to $10 \mathrm{~m}$ width are defined as surface watercourses and are displayed on TK25 as line objects; watercourses up to 10 to $20 \mathrm{~m}$ in width are line objects that are displayed with a special type of line; and objects wider than $20 \mathrm{~m}$ are displayed as areas. Therefore, the attribute value of an object from 5 to 10 $\mathrm{m}$ in width is unnecessary.

Thus, in the topographic model of CROTIS 2.1, the object entity of Hydrography (Fig. 6), the CodeList CategoryOfWidthType would contain the following values and attribute values codes:

\section{3 to $10 \mathrm{~m}: 1,10$ to $20 \mathrm{~m}: 2$, over $20 \mathrm{~m}: 3$}

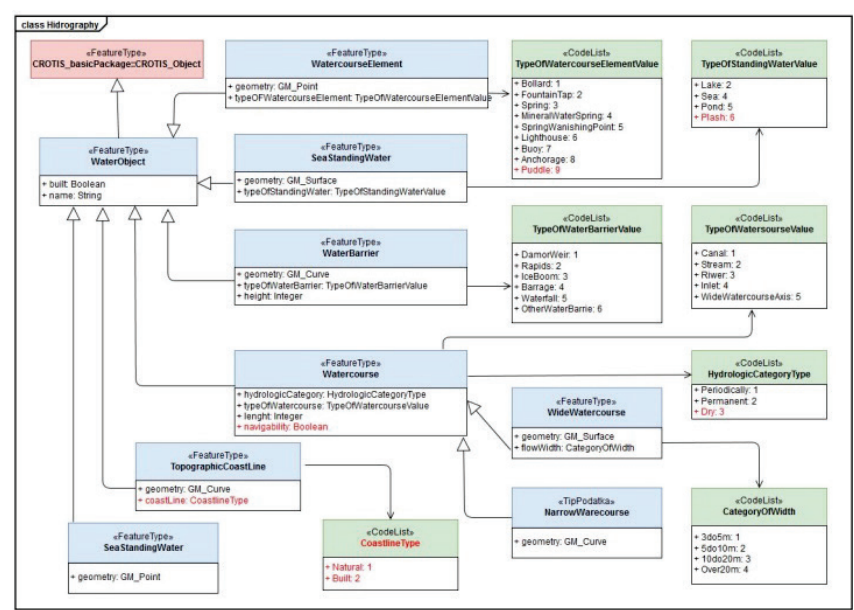

Figure 6 CROTIS 2.1_Hydrography

\section{CONCLUSION}

After the creation of the Official Topographic Cartographic Information System, STOKIS, as the basic document for the development of cartography in the Republic of Croatia, the Croatian Topographic Information System (CROTIS) was established in 1996. By establishing CROTIS, a topographic data model was defined.

Several versions of the topographic data model were made, including CROTIS 1.0, CROTIS 1.1, CROTIS 1.2 and finally CROTIS 2.0. The last version of the topographic data model, CROTIS 2.0, is in large proportion in line with the 
INSPIRE 2007/2/EC Directive. In the topographic data model of CROTIS 2.0, certain object classes have been replicated from one object entity to another object entity, and some object classes have been omitted because the State Geodetic Administration does not have the jurisdiction for it and the classes have not been collected for the Basic Topographic Database (TTB). According to the proposition from the topographic data model, the object entity of Geographical Names and the object entity of Utility Lines are excluded and those object entities will be placed in separate databases. This would be similar to CROTIS 1.2, when the object entities of Permanent Geodetic Points and of Administrative and Territorial Division and Boundaries were excluded and placed in a separate database.

From a detailed analysis of the topographic data model of CROTIS 2.0, and based on the experience in data collection and processing, a number of suggestions were made to improve the topographic data model. The proposal for improvement is given for the CROTIS basic package and for the thematic entity of Hydrography. For the basic package, the proposed change is in the StateOfObjectType code list. For the object entity of Hydrography it is given in the FeatureType Watercourse, and the proposal is to add the attribute of Navigability. It is also proposed to change the Code List for the TypeOfWatercourseElementValue, TypeOfStandingWaterValue, and HydrologicCategoryType. It is strongly advised to continue in the future a close cooperation with all interested parties (institutions) and to supplement and harmonize the existing data model with other spatial data users' data models. Advances in technologies that use spatial data create a growing need for spatial data both in the geometric and attributive form. Therefore, it is evident that this proposed cooperation is simply necessary and unavoidable.

\section{REFERENCES}

[1] Narodne novine. (2008). Pravilnik o topografskoj izmjeri i izradbi državnih karata, Narodne novine broj 107/08, Zagreb.

[2] Racetin, I. (2013). STOKIS u hrvatskoj pravnoj regulativi, Geod. list, 2, 135-144.

[3] Landek, I. (2017). Unapređenje modela topografskih podataka Republike Hrvatske, doktorska disertacija, Zagreb

[4] Frančula, N. \& Lovrić, P. (1993). Službeni topografskokartografski informacijski sustav - Idejni projekt, Državna geodetska uprava, Zagreb.

[5] Radić, Z. (1994). Restrukturiranje i reprogramiranje geodetsko-prostornog sustava Republike Hrvatske $s$ tehnološkom dogradnjom njegova informacijskog sustava $(u$ novim uvjetima samostalne, suverene države koja se uključuje $\mathrm{u}$ evropske sustave), Podprojekt provedba brzih promjena i konceptualna rješenja restruktuiranog geodetsko-prostornog sustava Republike Hrvatske (GEOPS), Državna geodetska uprava, Zagreb.

[6] Biljecki, Z. (1996). CROTIS-topografsko informacijski sustav Republike Hrvatske, Državna geodetska uprava, Zagreb.

[7] Divjak, D. (2013). Prijedlog poboljšanja postojećeg sustava na temelju dosadašnjih projekta $i$ iskustava, Državna geodetska uprava, Zagreb.

[8] Divjak, D. (2014). Hrvatski topografsko informacijski sustav 2.0 (CROTIS 2.0), Državna geodetska uprava, Zagreb.
[9] Landek, I., Marjanović, M., \& Šimat, I. (2014). Model podataka Hrvatskog topografsko informacijskog sustava CROTIS 2.0. Časopis Kartografija i geoinformacije, Zagreb, 2015, 30-51.

[10] Ključanin, S., Poslončec-Perić, V., Ponjavić, M., Karabegović, A., \& Landek, I. (2014). Strategija razvoja službene kartografije u Federaciji Bosni i Hercegovini, Dokument Federalne uprave za imovinsko-pravne poslove, Sarajevo.

[11] Ćosić, S., Alilović, M., Frangeš, S., \& Landek, I. (2012). Topografske karte na području Hrvatske, Državna geodetska uprava, Zagreb.

[12] Biljecki, Z. (1995). Studija o nadomještanju reprodukcijskih izvornika $i$ obnavljanja sadržaja topografskih zemljovida, Državna geodetska uprava, Zagreb

[13] Križaj, E. (1992). Studija o ustrojstvu službenoga topografsko kartografskog informacijskog sustava Republike Hrvatske, Državna geodetska uprava, Zagreb

[14] Mallgren, W. R. (1982). Formal specification of graphic data types. ACM Transactions of Programming Language and System, 4(4), 687-710. https://doi.org/10.1145/69622.357191

[15] Biljecki, Z. (2009). Implementacija rezultata projekta CROTIS-GML u postojeći document CROTIS 1.1, Državna geodetska uprava, Zagreb

\author{
Ivan LANDEK, PhD \\ State Geodetic Administration \\ Gruška 20, 10000 Zagreb, Croatia \\ Tel.+38516165422, ivan.landek@dgu.hr \\ Saša CVITKOVIĆ, B.Sc. in Geodesy \\ State Geodetic Administration \\ Gruška 20, 10000 Zagreb, Croatia \\ Tel.+38516165464, sasa.cvitkovic@dgu.hr \\ Milan REZO, PhD \\ Faculty of Geotehnical Engineering \\ Hallerova aleja 7, 42000 Varaždin, Croatia \\ Tel.+38542408900, mrezo@gfv.hr
}

